Prace Filologiczne. Literaturoznawstwo 10(13) 2020

ISSN 2084-6045

e-ISSN 2658-2503

Creative Commons: Uznanie autorstwa 3.0 PL (CC BY)

DOI: $10.32798 /$ pflit.575

\title{
THE FLYTING OF DUMBAR AND KENNEDIE AS AN INVERTED LITANY: THE SCOTTISH PERSPECTIVE ON A POETIC AGON*
}

\author{
The Flyting of Dumbar and Kennedie jako litania na opak: \\ szkockie spojrzenie na kwestię poetyckiego agonu
}

\section{DOMINIKA RUSZKIEWICZ}

Akademia Ignatianum w Krakowie, Polska

E-mail: dominika.ruszkiewicz@ignatianum.edu.pl

ORCID: 0000-0001-7809-587X

\section{Streszczenie}

Artykuł składa się z dwóch części. W pierwszej, szkocki gatunek pojedynku na słowa (flyting), którego głównym celem było upokorzenie przeciwnika, zostaje umiejscowiony w kontekście anglosaskiej tradycji kulturowej i literackiej. Druga część podejmuje stylistyczną analizę utworu pt. The Flyting of Dumbar and Kennedie, argumentując, że wykazuje on pokrewieństwo tematyczne z satyrą poetycką, jednocześnie zbliżając się pod względem formy do wiersza litanijnego. The Flyting nie tylko wykazuje pewne cechy formalne litanii, lecz podziela także jej obraz świata, z Bogiem jako mediatorem poetyckiego agonu. Widziane z tej perspektywy wrogie wymiany zniewag przedstawione $\mathrm{w}$ wierszu nie stanowią zaprzeczenia, a jedynie odwrócenie tradycji litanijnej, co sprawia, że utwór można uznać za przykład litanii na opak.

Słowa kluczowe: pojedynek na słowa, Szkocja, późne średniowiecze, wiersz litanijny, antonomazja, hiperbola

\section{Abstract}

This article is composed of two parts. In the first, the Scottish genre of flyting, whose main purpose was to humiliate the opponent, is situated in the context of the Anglo-Saxon cultural and literary tradition. The second offers a stylistic analysis of The Flyting of Dumbar and Kennedie, arguing that the poem shows thematic affinity with satiric verse while bearing formal resemblance to litanic verse. The Flyting not only displays certain features that are characteristic of the litanic form, but also shares the litanic worldview, with God as the mediator of the poetic agon.

\footnotetext{
${ }^{*}$ The publication of this article was subsidised by the University of Warsaw.
} 
Seen from this perspective, the poem's hostile exchanges of insults do not represent a negation, but merely a reversal of the litanic tradition, and The Flyting may be seen as an example of an inverted litany.

Keywords: flyting, Scotland, late Middle Ages, litanic verse, antonomasia, hyperbole

\section{The Flyting in its Cultural Context}

The Flyting of Dumbar and Kennedie represents a poetic duel between two late medieval Scottish poets: William Dunbar and Walter Kennedy. The poem, in which the contestants take turns to heap insults on each other, shows affinity with various traditions of verbal combat, whether of Greek (the agon tradition), ${ }^{1}$ Celtic, ${ }^{2}$ Provençal (the troubadour sirventes, tenso, and partimen), ${ }^{3}$ or - more recently - American provenance (the infamous "roasting" of public figures), ${ }^{4}$ and may be associated with settings as diverse as the brutal Roman arena ${ }^{5}$ and the pastoral idyllic landscape. ${ }^{6}$ It is perhaps for this reason that The Flyting is difficult to classify and interpret and has never been a favourite with the critics. In fact, it has been referred to as "the most repellent poem [...] in any language a penance to read and write about". ${ }^{7}$ It is a poem in which Christian values which formed the basis of Western civilization in the Middle Ages - are turned upside-down, and terms of praise for God and his creation are replaced with those of abuse. And yet, the language used by Dunbar and Kennedy abounds in apostrophes and other rhetorical figures that are characteristic of the Church litanies. My aim is to show that it is because of this extraordinary discrepancy between the form of the poem, modelled as it is upon a litanic enumeration of names, and its content, marked by obscenity and vulgarity, that the poem may be seen as an example of an inverted litany.

${ }^{1}$ Tom Scott, William Dunbar. A Critical Exposition of The Poems (Edinburgh/London: Oliver and Boyd, 1966), 175.

${ }^{2}$ Edwin Morgan, Crossing the Border: Essays on Scottish Literature (Manchester: Carcanet, 1990), 26-27.

${ }^{3}$ Roderick J. Lyall, Alexander Montgomerie. Poetry, Politics, and Cultural Change in Jacobean Scotland (Tempe, Arizona: Arizona Center for Medieval and Renaissance Studies, 2005), 79.

${ }^{4}$ Dorothy W. Riach, "Walter Kennedy's Part in The Flyting of Dunbar and Kennedie", in Scottish Language and Literature, Medieval and Renaissance: Fourth International Conference 1984: Proceedings, ed. Dietrich Strauss, Horst W. Drescher (Frankfurt am Main/New York: Peter Lang, 1986), 369.

${ }^{5}$ T. Scott, op. cit., 176-178.

${ }^{6}$ On the pastoral agon in Theocritus's Idyll, vide Sylwia Wojciechowska, (Re)Visions of the Pastoral in Selected British and American post-Romantic Fiction (Kraków: Wydawnictwo WAM, 2017), 28.

${ }^{7}$ T. Scott, op. cit., 175. 


\section{Heroic vs Ludic Flyting}

In Anglo-Saxon culture verbal duels have a long genealogy. First recorded in Old English, the term "flitan" was initially used in two senses: to strive or to dispute. ${ }^{8}$ The earliest specimens of flyting to be found in Anglo-Saxon literature include exchanges aimed at testing the truthfulness of the opponent's words, especially when he was a stranger, whose identity had to be verified and reputation tested. ${ }^{9}$ That was the case of the exchange between Beowulf, a newcomer to Hrothgar's court, and Unferth, a Danish thane. Provoked by Unferth, the verbal combat centres around the question of whether Beowulf's good name is firmly grounded in martial achievements or whether it rests solely on empty boasts, i.e. whether there is evidence of him actually performing the deeds that he is so proud of, such as winning the swimming-match with Breca, a sea monster. Responding to Unferth's challenge, Beowulf stresses the truthfulness of his account - "[...] the truth is as I've said: / I had more sea-strength, outstaying Breca's" (11. 532-533) ${ }^{10}$ - and launches a counterattack at his opponent by stating that Unferth, having killed only his kindred, has no achievements to match his (11. 587-588). Thus, in terms of its structure, the Beowulf-Unferth exchange follows the three-stage sequence consisting of a Claim, Defence, and Counterclaim, which is typical of debates. ${ }^{11}$ In terms of its content and function, it belongs to what Ward Parks refers to as "heroic flyting", which often served as a preliminary to a martial attack, such as in the case of the battle between Beowulf and Grendel. ${ }^{12}$

The Flyting of Dumbar and Kennedie, by contrast, belongs to "ludic flyting", 13 a phenomenon which had roots in social history. As argued by Priscilla Bawcutt, "In the later Middle Ages the nouns "flyte" and "flyting" signified noisy arguments, often taking place in public, and chiefly - or so, it was insinuated - carried on by women". ${ }^{14}$ The frequent occurrence of such noisy, public quarrels on Scottish streets has been recorded in both city documentation and poetry, including Dunbar's To the Merchantis of Edinburgh, which evokes the "cryis of carlingis and debaittis [cries of old women and debates]" (1. 10) as well as "feusum

${ }^{8}$ Priscilla Bawcutt, “The Art of Flyting”, Scottish Literary Journal, vol. 10 (1983): 7; E. Morgan, op. cit., 26.

${ }^{9}$ Cf. Carol J. Clover, "The Germanic Context of The Unferp Episode”, Speculum, vol. 55 (1980): 451.

${ }^{10}$ Cit. per Beowulf, trans. Michael Alexander (London: Penguin Books Ltd, 2001).

${ }^{11}$ C. J. Clover, op. cit., 452.

${ }^{12}$ Ward Parks, "Flyting, Sounding, Debate: Three Verbal Contest Genres", Poetics Today, vol. 7 (1986): 441, 444.

${ }^{13}$ For the distinction between "heroic" and "ludic" flyting, vide ibidem, 444-453.

${ }^{14}$ P. Bawcutt 1983, op. cit., 7. 
flyttingis of defame [foul, defamatory flytings]" (1. 11) that could be heard on the streets of Edinburgh. ${ }^{15}$

This is to say that the term "flyting" originally referred to a popular and typically Scottish phenomenon, consisting in abusive exchanges of insults, for as Kurt Wittig notes - it is the Scots that have developed a particularly passionate predilection for argument. ${ }^{16}$ Such exchanges were punishable by law and public penance was often ordained. On such occasions, the accused had to beg forgiveness from the victims of their slander, uttering the following words: "False tongue, thou lied". ${ }^{17}$ This implies that the ludic insults were not solidly grounded in real life and, therefore, were not customarily intended to be taken in earnest, often having a purely "entertaining" value. Thus, although the term "flyting" has by now acquired a generic status, ${ }^{18}$ the original context in which it was used was wider than the literary.

\section{The Scottish Protagonists of the Poetic Tournament}

The most representative poetic flytings of the ludic type were composed in sixteenth-century Scotland and include, among others, The Flyting of Dumbar and Kennedie (1508), one of the first poems to be printed in Middle Scots. George Bannatyne, the compiler of the Bannatyne Manuscript, which is the principal source for the poem, places The Flyting of Dumbar and Kennedie in a group of "balletis mirry" and introduces the poem in the following words: "The Flyting of Dumbar and Kennedie / here efter followis Iocound and mirrie" (f. 147 ${ }^{\mathrm{r}}$ ), ${ }^{19}$ thereby guiding his readers towards a playful reception of the poetic quarrel, ${ }^{20}$ a quarrel which extends over five hundred and fifty-two lines, two hundred and forty-eight of which are attributed to Dunbar, while the remaining three hundred and four to Kennedy.

In The Flyting, the antagonistic relation between the poets is depicted in terms of a formal tournament, for both opponents are accompanied by their seconds:

${ }^{15}$ All quotations from Dunbar's poems come from Jacqueline A. Tasioulas (ed.), The Makars. The Poems of Henryson, Dunbar and Douglas (Edinburgh: Canongate Books, 1999). For translations into modern English provided in brackets, I use notes in ibidem and P. Bawcutt (ed.), William Dunbar. Selected Poems (London and New York: Longman, 1996).

${ }^{16}$ Kurt Wittig, The Scottish Tradition in Literature (Edinburgh: Oliver and Boyd, 1958), 76.

${ }^{17}$ P. Bawcutt 1983, op. cit., 8-9.

${ }^{18}$ Cf. ibidem, op. cit., 6-7.

${ }^{19}$ The Poems of Walter Kennedy, ed. Nicole Meier (Woodbridge: The Scottish Text Society, 2008), xviii.

${ }^{20}$ For more information on Bannatyne's editing procedures, vide William Ramson, "On Bannatyne's Editing", in Bards and Makars. Scottish Language and Literature: Medieval and Renaissance, eds. Adam J. Aitken, Matthew P. McDiarmid, Derick S. Thomson (Glasgow: University of Glasgow Press, 1977), 172-183. 
Sir John Ross in the case of Dunbar (1.1) and "my cousing Quintene and my commissar" in the case of Kennedy (1.34). ${ }^{21}$ Moreover, both poets mention fighting, armour, and battlefield. Before accepting the challenge, Dunbar says: "Thow speiris, dastard, gif I dar with the fecht. [You ask, coward, if I dare fight with you.] / Ye, Dagone dowbart, thairof haif thow no dowt [Yes, idolatrous fool, have no doubt of this]" (11. 65-66). Positioning himself as a warrior, Dunbar boasts that he will need neither knife, sword, nor axe to fight his opponent; he will use a dog leash instead (ll. 71-72). "Durch, I shall ding thee [Dwarf, I shall hit you]" (1. 395), replies Kennedy, and in the final stanza asks Dunbar to surrender his "spear of war" (1. 545) and "flee the field" (1. 547). The "field" in question might have been the royal court, for the poem contains a reference to winter (1. 118), which is when such courtly entertainments would take place, and a direct address to King James IV (1l. 481-482), in whose presence the flyting might have been performed, thereby earning the poets their credentials. ${ }^{22}$

In fact, no conclusive evidence exists to confirm that such verbal duels were intended to cause suffering or distress to the opponent, just like no hard feelings of personal hostility towards his poetic adversary could be ascribed to either Dunbar or Kennedy. On the contrary, flyting may be "most satisfying between friends" in that "it enables words to be used, and things to be said, that otherwise could not, without bloodshed". ${ }^{23}$ The respect the poets had for each other is attested to in other Scottish works, such as Dunbar's Lament for the Makars, in which the poet refers to "[g]ud maister Walter Kennedy" (1. 89), as well as in David Laing's "Account of the Contents of the Bannatyne Manuscript", in which Dunbar appears as Kennedy's friend.$^{24}$ It seems, therefore, that the poets decide to engage in a verbal combat purely for its own sake. This is to say that even though the insults are apparently intended to ridicule their opponent's character flaws and actions, they do not add up to a coherent portrait of either poet. Instead, they reveal some of the social and cultural forces at work in fifteenth-century Scotland which were responsible for a major linguistic shift, as a result of which Middle Scots emerged as the dominant language, replacing the aristocratic French in such areas of life as culture,

${ }^{21}$ The first 248 lines of the Flyting, i.e. the whole of Dunbar's contribution and the beginning of Kennedy's, are quoted from J. A. Tasioulas, op. cit. For the remaining lines, I resort to "The Flyting of Dunbar and Kennedy by William Dunbar normalized and glossed by Michael Murphy", accessed from Clan Strachan Society website (http://www.clanstrachan.org/history/ Flyting_of_Dunbar_and_Kennedy.pdf).

${ }^{22}$ R. J. Lyall notes that Dunbar was granted a pension by James IV around the time in which the poem was composed, which may not be coincidental. Vide R. J. Lyall, op. cit., 79.

${ }^{23} \mathrm{~K}$. Wittig, op. cit., 76.

${ }^{24}$ D. W. Riach, op. cit., 378. 
literature, and government, and degrading the familial Gaelic to the status of a second-class language. ${ }^{25}$

The animosity between the Scots-speaking and Gaelic-speaking population surfaces on numerous occasions in the poem, especially those where Dunbar mocks Kennedy for his provincial descent and predilection for a lower kind of verse composed in the Gaelic language (11. 106-112), and where Kennedy defends Gaelic, stating that it should be the true language of every Scotsperson, and blames Dunbar's forefathers for its decline (11. 345-352). However strongly the poets feel about the Scottish heritage, their biting insults aimed at their opponent's ethnic and linguistic background are not based on facts. ${ }^{26}$ Thus, while it is true that Kennedy's family came from a Gaelic-speaking part of Scotland, it is certainly unlikely that the poet himself may be taken for the "Iersche brybour baird [Highland vagabond bard]" (1.49) or "Ersch katherene [Gaelic-speaking robber]" (1.145), as he is described by Dunbar. In this respect, the poem is not a reliable historical source and should not be treated as "a quarry for precise biographical data". ${ }^{27}$

\section{The Flyting vs Satiric and Argumentative Verse}

Instead of providing verifiable historical referents, The Flyting is based on well-established stereotypes that are used in works of social satire and offer a distorted picture of reality. Therefore, it is possible to detect a certain thematic affinity shared by the two genres, for both the flyting and the satire can be defined as verbal assaults carried out by means of stereotypes. The flyting, however, is a more direct, undisguised attack and - even though there are instances of what Tom Scott calls "genuine satire" in The Flyting too - its purpose is not to expose and correct the vices of an individual, but rather to "destroy" the object of its attack through personal vilification. ${ }^{28}$ Therefore, what the flyting shares with the satire is a mere thematic affinity rather than a genuine connection.

The same seems true of the relation between the flyting and those polemical dialogues in which the contesting sides support a specific position through an extended argument. As has already been noted, apart from the linguistic argument mentioned above, there is very little material in The Flyting of Dumbar and Kennedie that would qualify as a meaningful discursive exchange. Instead, the poetic adversaries move from one insult to another, creating catalogues

${ }^{25}$ For more information on the linguistic situation in late medieval Scotland, vide Jenny Wormald, Court, Kirk, and Community, Scotland 1470-1625 (Edinburgh: Edinburgh University Press, 1981), 59-63.

${ }^{26}$ W. Parks, op. cit., 446-447.

${ }^{27}$ P. Bawcutt 1983, op. cit., 21.

${ }^{28}$ For more details, vide T. Scott, op. cit., 174-176. 
of names, which are the most distinguishing feature of the poem. The poets' preoccupation with the syntactic form further distances The Flyting from argumentative verse and brings it closer to highly patterned forms of verse, such as the litanic verse. ${ }^{29}$ The relation between The Flyting and litanic verse is much less obvious than that between the Scottish poem and satiric verse, or in no respect obvious at all, and yet - as shall be argued below - The Flyting may be seen as an inverted litany, both in terms of its form and the worldview it promotes. ${ }^{30}$

\section{The Flyting and Litanic Verse}

Litanies of titles honouring the saints, most notably the Virgin Mary, were certainly known in Scotland, for - as shown by religious scholars - late medieval Scotland was not indifferent to the general European upsurge in lay spirituality. Coinciding with the period of frequent military invasions and outbreaks of the plague, in Scotland - as in the rest of Europe - this movement may have been fuelled by a concern about the soul's spiritual future, and it manifested itself in the support for the Church institutions, pilgrimages, and the veneration of the saints, such as the Virgin Mary, who was believed to intercede with God for the salvation of mankind. In fact, Mary's intercessory powers were evoked in an act of the Scottish Parliament on 14 March 1541 in the context of benefits they can bring to both individuals and the state, as well as in prayers, such as "The Lang Rosair", "O Clementissime", "Ave Maria Alta Stirps", and "O Intemerata", among others. ${ }^{31}$ It has also been established that wealthy Scots were in the possession of devotional books of either Flemish or French origin, which included litanies too, such as for instance the "Litany of Our Lady". ${ }^{32}$

The influence of Marian devotion, as is argued in this paper, extended to poems that have seemingly very little connection to lay piety, such as The Flyting,

${ }^{29}$ The term "litanic verse" has been introduced by Witold Sadowski. Cf. W. Sadowski, Litania i poezja. Na materiale literatury polskiej od XI do XXI wieku [Litany and Poetry. On the Body of Material of Polish Literature from the Eleventh to the Twenty-First Century] (Warszawa: Wydawnictwa Uniwersytetu Warszawskiego, 2011), 111-145; W. Sadowski, European Litanic Verse. A Different Space-Time (Berlin: Peter Lang, 2018), 23-25.

${ }^{30}$ Examples of other inverted litanies have been examined by Katarzyna Dudek, "Our Lady of Controversy: Defamiliarization of the Litanic Verse in English Poetry (1837-1939)", in Litanic Verse II. Britannia, Germania et Scandinavia, eds. Witold Sadowski, Magdalena Kowalska, Magdalena M. Kubas (Frankfurt am Main: Peter Lang, 2016), 118-127; Małgorzata Gorczyńska, “»Krleš! Krleš! Krleš! «: Litany and its Derivatives in Czech Literature to the 1930s”, trans. Dominika Ruszkiewicz, in Litanic Verse I, Origines, Iberia, Slavia et Europa Media, eds. Witold Sadowski, Magdalena Kowalska, Magdalena M. Kubas (Frankfurt am Main: Peter Lang, 2016), 295-299; and W. Sadowski, "Polish Litanic Verse until 1939: An Outside Perspective", in Litanic Verse I, op. cit., 338-342.

${ }^{31}$ Audrey-Beth Fitch, The Search for Salvation. Lay Faith in Scotland, 1480-1560, ed. Elizabeth Ewan (Edinburgh: John Donald, 2009), 113-150.

${ }^{32}$ Ibidem, 144. 
which is not only based on the syntactic arrangement of text that is characteristic of litanies ${ }^{33}$ but also contains three necessary components of litanic verse ${ }^{34}$ : the ektenial gene, which is responsible for the enumeration of intentions, the chairetismic gene, responsible for laudatory or acclamatory prayers ${ }^{35}$ and the polyonymic gene, responsible for long lists of names. ${ }^{36}$ The combination of genes which is particularly relevant for medieval European literature is the chairetismicpolyonymic pairing, based on the Greek Akathist Hymn. It appears most frequently in medieval laudatory poems addressed to the Mother of God, known as "hail lyrics", but is not restricted to the religious context. In fact, also secular occasional poems, which are composed in praise of a specific individual, often rely on repetitive calls or addresses equivalent to the Latin greetings ave, salve, gaude, or vale, as well as on a frequent use of antonomasia. ${ }^{37}$ It is such poems, structured around a call or an address, that constitute a major part of Dunbar's works. ${ }^{38}$

The Flyting of Dumbar and Kennedie is a good illustration of how the chairetismic-polyonymic pair of genes operates within the poem, with the latter being the dominant gene. The potential of the polyonymic gene is realised through debasing antonomastic epithets applied to the two opponents engaged in a verbal fight: Dunbar and Kennedy. The number of insulting names varies from line to line, starting with two: "[s]kaldit skaitbird and commoun skamelar [scabby vulture and common scavenger]" (1.37); moving to three in the following example: "[i]gnorant elf, aip, owll irregular [ignorant elf, ape, lawless owl]" (1. 36); and ending with as many as four names in the following sequence, among others: "[h]erretyk, lunatyk, purspyk, carlingis pet [heretic, lunatic, pickpocket, old woman's fart]" (1. 247). It is interesting to note that the density of names increases towards the end of the poem, both in the case of Dunbar's as well as Kennedy's parts, until it reaches a poetic climax in their last stanzas, which are reduced to being mere "exercises in name-calling". 39

The chairetismic dimension of the poem is manifested in the use of direct calls to an addressee, which contain either a greeting or the name of the addressee. The salutatory "hail" is used once in Dunbar's attack on Kennedy (1. 104).

${ }^{33}$ W. Sadowski 2018, op. cit., 20.

${ }^{34}$ These components will be referred to as "genes" following the terminology introduced by Witold Sadowski in his Litania i poezja [Litany and Poetry], op. cit., 25-68.

${ }^{35}$ W. Sadowski 2018, op. cit., 113-114.

${ }^{36}$ Ibidem, 136-137.

${ }^{37}$ Ibidem, 225.

${ }^{38}$ Dunbar's indebtedness to the medieval tradition of Marian lyrics has already been examined in relation to both his courtly and devotional poems. Cf. Dominika Ruszkiewicz, "»Thy name I sall ay nevyne «: Litanic Verse in Fifteenth-Century England and Scotland”, in Litanic Verse II, op. cit., 42-47.

${ }^{39}$ P. Bawcutt, Dunbar the Makar (Oxford: Clarendon Press, 1992), 357. 
In other cases, the Marian verbal apostrophe is replaced by an interjection of disgust and disapprobation - "fy", as in stanza eleven: "Fy, tratour theif, fy, Ganelyon, fy, fy! [Fie, treacherous thief, fie, Ganelon, fie, fie!]" (1. 83). The line quoted above also contains a nominal reference to the addressee, "Ganelyon", preceded by an antonomasia, "tratour theif". Such sequences represent a combination of the chairetismic and polyonymic genes. However, unlike the holy names that are repeated in each line of litanic prayers, in the Scottish flyting none of the initial nouns gains the status of a central name, with a new name being evoked each time.

The ektenial gene is less frequently used in The Flyting, for neither of the opponents calls upon God for help or asks his antagonist's mercy. They are nevertheless challenged to beg mercy or surrender. As Dunbar says to Kennedy: "Cry grace, tykis face, or I the chece and fley [Implore mercy, dog's face, or I will frighten you off]" (1.235).

Among other litanic features that the poem exhibits, there is also the use of hyperbole, which in a litanic context serves to underline the unmatched, surpassing quality of the described holy person. In The Flyting, the same convention - referred to by Ernst Robert Curtius as "the panegyrical topos of outdoing" 40 - is used for a very different purpose, namely to depict the poets as supreme examples of evil. This is how Dunbar refers to Kennedy: "Thow crop and rute of tratouris tressonable [Thou, the supreme example of treacherous traitors], / The fathir and moder of morthour and mischeif [The father and mother of murder and mischief]" (11. 73-74).

Thus, even though at the syntactic level The Flyting resembles a litany, in terms of its theme and style it is a direct inversion of the litanic convention. Instead of rounds of prayer, the poem is based on "successive rounds of combative verse". ${ }^{41}$ Rather than compete to outdo one another in their praise of God, the poets "strive to out-insult each other". ${ }^{42}$ Their main aim is not to deify, but to humiliate and abuse, which explains why positive antonomasias give way to negative, and laudatory purpose is replaced with imprecatory.

\section{The Silent Presence of God}

The inversion of "high" and "low", however, does not automatically entail the assumption of a radically different worldview, even though the imagery used in the poem is at times truly infernal, especially in those passages in which

${ }^{40}$ Ernst Robert Curtius, European Literature and the Latin Middle Ages, trans. Willard Ropes Trask (Princeton: Princeton University Press, 1953), 162.

${ }^{41}$ Elizabeth Evershed, "Flyting", in The Facts on File Companion to British Poetry Before 1600, ed. Michelle M. Sauer (New York: Infobase Publishing, 2008), 190.

${ }^{42}$ Ibidem. 
the poets refer to their opponent's inhuman, devilish genealogy. ${ }^{43}$ And yet, the worldview promoted in the poem is not one in which "two kingdoms for example the kingdom of God and the kingdom of Satan - stand face-to-face with their armed forces". ${ }^{44}$ In fact, even poems as different from the hail lyrics as the flytings may be seen as promoting a God-centred worldview, which bears resemblance to that adopted in the litany, as long as the evil they depict is not meant to be seen as autonomous, but rather "as a starting point for the work which needs to be done in order to bring man closer to God" ${ }^{45}$ This seems to be the case in The Flyting, which evokes images of the apocalypse (11. 9-16), together with pleas for God's mercy, such as "Say »Deo mercy«, or I cry the doun [Say mercy, for God's sake, or I will denounce you]", among others (1. 31). While it may be argued that such words serve to further humiliate a poetic opponent, to whom they are addressed, they also point to God as the ultimate dispenser of justice.

It is through the litanic form, in which the poem is framed, rather than through its semantic content that the divine presence is introduced in The Flyting. ${ }^{46}$ Similarly to other litanic poems, also in The Flyting God appears as "the indivisible source" of the space-time and "the source of infinite variety". ${ }^{47}$ His silent presence in the poem is manifested at the level of syntax, which is based on the coexistence of elements that are constant and thereby represent God's oneness, and those that are changeable and as such represent the manyness of His creation. The tension between the repeatable and the changeable elements can best be seen in stanzas twenty-one to twenty-five of The Flyting, which contain the anaphoric thy-phrase, followed by the various attributes of Kennedy, as listed by Dunbar:

Thy rigbane rattillis and thy ribbis on raw,

[Your backbone rattles and your ribs in a row,]

Thy hanchis hirklis with hukebanis harth and haw,

[Your haunches crouch together with hip-bones rough and blue,]

Thy laithly lymis ar lene as ony treis.

[Your loathy limbs are as lean as twigs.] (11. 180-182)

${ }^{43}$ In Dunbar's concluding stanza, Kennedy is referred to as "feyindis gett [devil's spawn]" (1. 244). Similarly, Dunbar appears as "Lucifer's lad, foul fiend's face infernal, / Sodomite separate from saints celestial” (11. 252-253).

${ }^{44}$ W. Sadowski 2018, op. cit., 276.

${ }^{45}$ Ibidem, 277.

${ }^{46}$ The litanic worldview forms the underlying "operating system" of the poem and - in contrast to the surface layer of the poem - remains unseen. For a distinction between the semantic scope of the text and the generic worldview, vide W. Sadowski 2018, op. cit., 231.

${ }^{47}$ W. Sadowski 2018, op. cit., 243. 
The repeatable element on the left side of the line represents God as the source of the universe, whereas the changeable elements on its right stand for the many rays that extend from the indivisible source and symbolise the abundance of His universe. To make the lines quoted above more prayer-like, a verbal element could be added before the enumeration of various body parts. In fact, Marian lyrics often employed benedictory formulas, such as "blessed be", which anticipated the list of Mary's physical attributes. ${ }^{48}$ In the context of the flyting, a more fitting formula would be the maledictory "cursed be".

The inversion of the benedictory formula does not lead to the negation of the litanic space-time, but merely to a defamiliarization of the litanic pattern. ${ }^{49}$ In other words, both benediction and malediction, even though they tend to be uttered in very different contexts and for different purposes, coexist within the same theocentric universe of litanic poetry. This is because both are based on the belief in the central role of God (cf. Ecclesiasticus 33: 11-12) and the power of our words, to which He listens and in His grace responds. The concept of God's mercy seems to be as potent in The Flyting as it is in the litany, for both rest on a belief that invoking God's name will result in His intervention, an intervention that seems particularly welcome in the case of a quarrel that is not only unresolved, ${ }^{50}$ but also does not make it clear which of the two contestants plays the role of the protagonist and which is the antagonist.

An undisputed although invisible protagonist of the poem is God, who enters the poem by means of the litanic verse in order to reconcile the contending parties and restore peace through the example of His merciful forgiveness. Perhaps we may make one further point and suggest that He is not only a silent witness of the poetic agon, but also its indirect instigator and enabler, for what lies at the root of the quarrel between the two Scottish poets is a desire to demonstrate their mastery over language - one of God's gifts to man. By using the inexhaustible resources of language, both Dunbar and Kennedy seem to celebrate the abundance of His creation rather than merely their own creative powers, abundance which extends over various geographical and cultural areas, including the Highlands and Lowlands, as well as various languages. It is this playfully celebratory purpose, it seems, that unites both poets and contributes to their common victory in the agon.

${ }^{48}$ Vide, for instance, Walter Kennedy's praise of the Virgin Mary in his "Ane Ballat of Our Lady", 11. 51-54, in The Poems of Walter Kennedy, op. cit., 14-15.

${ }^{49}$ For more information on the defamiliarization of the litanic pattern, vide W. Sadowski 2011, op. cit., 272-289.

${ }^{50}$ Even though some critics, such as Dorothy W. Riach, claim that the poet who has the last word, i.e. Kennedy, is the winner of the poetic agon, a typical Scottish flyting ended with an appeal to the audience to pass their judgement on the competitors, which was probably done by means of applause. Vide D. W. Riach, op. cit., 378; E. Morgan, op. cit., 30. 


\section{Bibliography}

Bawcutt, Priscilla. "The Art of Flyting”. Scottish Literary Journal, vol. 10 (1983): 5-24. Bawcutt, Priscilla. Dunbar the Makar. Oxford: Clarendon Press, 1992.

Bawcutt, Priscilla (ed.). William Dunbar. Selected Poems. London/New York: Longman, 1996.

Beowulf, trans. Michael Alexander. London: Penguin Books Ltd, 2001.

Clover, Carol J. "The Germanic Context of The Unferp Episode". Speculum, vol. 55 (1980): 444-468.

Curtius, Ernst Robert. European Literature and the Latin Middle Ages, trans. Willard Ropes Trask. Princeton: Princeton University Press, 1953.

Dudek, Katarzyna. "Our Lady of Controversy: Defamiliarization of the Litanic Verse in English Poetry (1837-1939)”. In Litanic Verse II. Britannia, Germania et Scandinavia, eds. Witold Sadowski, Magdalena Kowalska, Magdalena Maria Kubas. Frankfurt am Main: Peter Lang, 2016, 107-132.

Evershed, Elizabeth. "Flyting". In The Facts on File Companion to British Poetry Before 1600, ed. Michelle M. Sauer. New York: Infobase Publishing, 2008, 190.

Fitch, Audrey-Beth. The Search for Salvation. Lay Faith in Scotland, 1480-1560, ed. Elizabeth Ewan. Edinburgh: John Donald, 2009.

Gorczyńska, Małgorzata. “»Krleš! Krleš! Krleš!«: Litany and its Derivatives in Czech Literature to the 1930s", trans. Dominika Ruszkiewicz. In Litanic Verse I, Origines, Iberia, Slavia et Europa Media, eds. Witold Sadowski, Magdalena Kowalska, Magdalena Maria Kubas. Frankfurt am Main: Peter Lang, 2016, 285-301.

Lyall, Roderick J. Alexander Montgomerie. Poetry, Politics, and Cultural Change in Jacobean Scotland. Tempe, Arizona: Arizona Center for Medieval and Renaissance Studies, 2005.

Morgan, Edwin. Crossing the Border: Essays on Scottish Literature. Manchester: Carcanet, 1990.

Parks, Ward. "Flyting, Sounding, Debate: Three Verbal Contest Genres”. Poetics Today, vol. 7 (1986): 439-458.

Ramson, William. “On Bannatyne's Editing”. In Bards and Makars. Scottish Language and Literature: Medieval and Renaissance, eds. Adam J. Aitken, Matthew P. McDiarmid, Derick S. Thomson. Glasgow: University of Glasgow Press, 1977, 172-183.

Riach, Dorothy W. "Walter Kennedy's Part in The Flyting of Dunbar and Kennedie". In Scottish Language and Literature, Medieval and Renaissance: Fourth International Conference 1984: Proceedings, eds. Dietrich Strauss, Horst W. Drescher. Frankfurt am Main/New York: Peter Lang, 1986, 369-379.

Ruszkiewicz, Dominika. “»Thy name I sall ay nevyne«: Litanic Verse in Fifteenth-Century England and Scotland”. In Litanic Verse II. Britannia, Germania, et Scandinavia, eds. Witold Sadowski, Magdalena Kowalska, Magdalena Maria Kubas. Frankfurt am Main: Peter Lang, 2016, 31-50.

Sadowski, Witold. Litania i poezja. Na materiale literatury polskiej od XI do XXI wieku [Litany and Poetry. On the Body of Material of Polish Literature from the Eleventh to the Twenty-First Century]. Warszawa: Wydawnictwa Uniwersytetu Warszawskiego, 2011. 
Sadowski, Witold. "Polish Litanic Verse until 1939: An Outside Perspective". In Litanic Verse I, Origines, Iberia, Slavia et Europa Media, eds. Witold Sadowski, Magdalena Kowalska, Magdalena Maria Kubas. Frankfurt am Main: Peter Lang, 2016, 323-346. Sadowski, Witold. European Litanic Verse. A Different Space-Time. Berlin: Peter Lang, 2018.

Scott, Tom. William Dunbar. A Critical Exposition of The Poems. Edinburgh/London: Oliver and Boyd, 1966.

Tasioulas, Jacqueline A. (ed.). The Makars. The Poems of Henryson, Dunbar and Douglas. Edinburgh: Canongate Books, 1999.

The Flyting of Dunbar and Kennedy by William Dunbar, normalized and glossed by Michael Murphy, accessed from Clan Strachan Society website (http://www.clanstrachan.org/ history/Flyting_of_Dunbar_and_Kennedy.pdf).

The Poems of Walter Kennedy, ed. Nicole Meier. Woodbridge: The Scottish Text Society, 2008.

Wittig, Kurt. The Scottish Tradition in Literature. Edinburgh: Oliver and Boyd, 1958. Wojciechowska, Sylwia. (Re)Visions of the Pastoral in Selected British and American post-Romantic Fiction. Kraków: Wydawnictwo WAM, 2017.

Wormald, Jenny. Court, Kirk, and Community, Scotland 1470-1625. Edinburgh: Edinburgh University Press, 1981.

DOMINIKA RUSZKIEWICZ is an assistant professor at the Jesuit University Ignatianum in Kraków. Her research interests revolve around English and Scottish medieval literature, especially the poetry of Geoffrey Chaucer, Robert Henryson, and William Dunbar. She is a member of the research team working on the project "Litanic Verse in the Culture of European Regions". 